\title{
Transformational change leadership framework for implementing Broad-Based Black Economic Empowerment in South African organisations
}

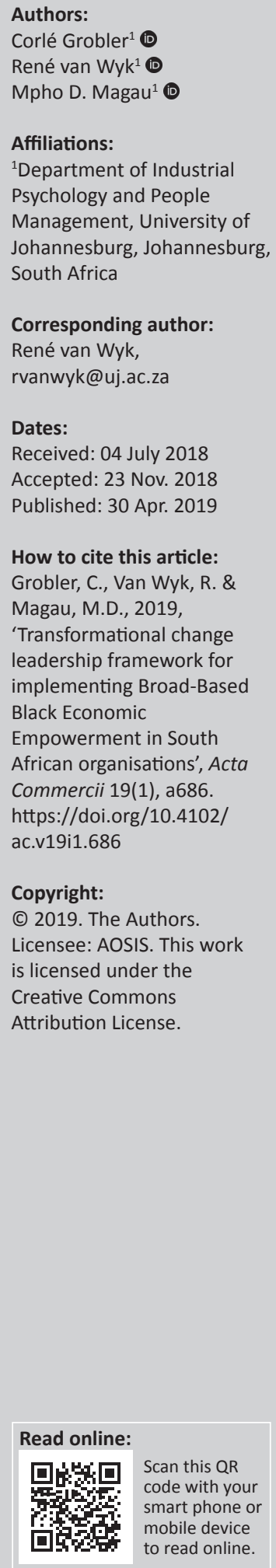

Orientation: This multiple qualitative case study provides a change leadership framework through augmentation of Kotter's eight-step change leadership model. This framework provides practical guidelines for the implementation of Broad-Based Black Economic Empowerment (B-BBEE).

Research purpose: To establish a transformational change leadership framework for B-BBEE implementation, applying Kotter's eight-step change leadership model.

Motivation for the study: It is not clear to what extent a transformational change leadership framework can be applied for the improved implementation of B-BBEE in South African organisations.

Research design, approach and method: This is a multiple qualitative case study with a constructivist philosophy. Sixteen organisations were purposively selected from the Top 100 rated Most Empowered Companies. Five B-BBEE transformation experts were selected for interviewing. The five participants were executives aged between 35 and 50 years: female (4), male (1), black people (2) and white people (3). Deductive thematic analysis was done using pre-defined themes and Kotter's change leadership steps. Inductive perspectives were applied when new insights were gained.

Main findings: The transformational change leadership framework for the implementation of B-BBEE incorporated Kotter's steps and additional essential elements.

Practical/managerial implications: The study proposes that a transformational change leadership framework could be used for implementing successful, sustainable B-BBEE in South Africa.

Contribution/value-add: Different elements contributed the B-BBEE transformational change leadership framework, namely: the role of leadership; leaders' personal commitment, values and beliefs; and support in driving effective transformation. A willing culture seems essential for sustainable climate of change that leads to transformation maturity.

Keywords: B-BBEE; Kotter's eight-step change model; transformational change; transformational leadership; sustained transformation; economic empowerment.

\section{Introduction}

Since 1993 the South African government has created a comprehensive, progressive legislative framework for the redress of social, economic and political inequalities and the transformation of the economy (Denton \& Vloeberghs 2003; Horwitz \& Jain 2011). South African businesses are subject to an array of laws and regulations that influence their operational capabilities and competitiveness (Krüger 2014). The Broad-Based Black Economic Empowerment (B-BBEE) Act (2013), in particular, and the requirements of the B-BBEE: Codes of Good Practice (2013) have far reaching implications for conducting business in South Africa.

Although a plethora of legislation has been implemented to drive transformation in South Africa, implementation is difficult and most transformation efforts fail. Several studies provide insight into reasons for failure to bring about true transformation. These include: a lack of commitment from leadership or management (Booysen 2007; Krüger 2011); leadership failure to understand the complex nature of transformation (Leonard \& Grobler 2006); white fears (Booysen 2007), negative perceptions towards B-BBEE (Krüger 2011); the abuse of the term 
transformation to the state of repulsiveness to some (Cronje 2015); the absence of the required psychological buy-in to achieve greater transformation (Knowledge Resources \& Mandate Molefi HR Consultants 2016); a disconnect between policy and implementation, leading to a lack of focus, coordination, understanding and integration of transformation efforts (Booysen 2007; Leonard \& Grobler 2006); resistance to and rejection of B-BBEE (Krüger 2014); as well as some organisations and/or people viewing B-BBEE as a 'cost of doing business in South Africa' and not as a transformation mechanism (Woolley 2014). BroadBased Black Economic Empowerment is often managed as 'an event or a project with a budget that must meet a target' (Cronje 2015). To move from mere compliance and implementing B-BBEE as a tick-box exercise, a new comprehensive approach is required to address the changed transformational landscape (Nkosi 2017). This process of social transformation necessitates thoughtful, managed change (Arya \& Bassi 2009).

The current situation leads to the main research question: To what extent can a transformational change leadership framework be applied for the improved implementation of B-BBEE in South African organisations? The objectives were to:

- describe the nature of transformational requirements on South African organisations, as well as the dynamics at play in the implementation of B-BBEE

- establish whether organisations used formal change management principles or models for the implementation of B-BBEE

- determine to what extent Kotter's eight-step change leadership model could be applied in the implementation of B-BBEE.

\section{Transformation requirements and existing change models in the literature}

The literature review included general legislative transformation requirements, B-BBEE transformation requirements specifically, and the need for transformational change leadership.

\section{The South African legal framework since 1993}

The first democratically elected South African government inherited a suffering economy with the highest inequalities in wealth and income distribution in the world (Emuze \& Adlam 2013). There was limited economic participation from black people because of the historic racial segmentation of the economy. The government realised that to enforce social transformation, transformation efforts could not be voluntary (Arya \& Bassi 2009). A number of acts were promulgated to address non-discrimination, employment equity, social and economic transformation. The statutes impacting South African businesses are indicated in Figure 1. The release of the B-BBEE Act in 2003 was the culmination of the efforts to redress economic transformation (Arya \& Bassi 2009).

\section{Broad-Based Black Economic Empowerment}

Broad-Based Black Economic Empowerment is an integrated, coherent socio-economic process to contribute to the transformation of South Africa (Vassan 2015). It aims to significantly increase black ownership, control and participation in the economy, and to substantially decrease income equalities. It endeavours to ensure the sustainable creation and offering of equitable opportunities to black South Africans (Woolley 2014). More than 20 years as a democracy, and despite all the legislative interventions, the country still faces immense, continued challenges of unemployment, inequality, poverty and low wages (Valodia \& Francis 2016). According to the B-BBEE Commission, the more stringent 2013 Codes is what was required to drive transformation (Padayachy 2016). These challenging requirements demand a robust response

\begin{tabular}{|c|c|c|}
\hline 1993 & & Interim Constitution Act No. 200 \\
\hline 1994 & & Restitution of Land Rights Act No. 22 \\
\hline 1995 & & Labour Relations Act No. 66 \\
\hline 1996 & & Constitution Act No. 108 \\
\hline 1997 & & Basic Conditions of Employment Act No. 75 \\
\hline 1998 & & $\begin{array}{l}\text { Employment Equity Act No. } 55 \\
\text { Skills Development Act No. } 97 \\
\text { National Empowerment Fund Act No. } 105\end{array}$ \\
\hline 1999 & & Skills Development Levies Act No. 75 \\
\hline 2000 & & $\begin{array}{l}\text { Preferential Procurement Policy Framework Act No. } 5 \\
\text { Promotion of Equality and Prevention of Unfair Discrimination } \\
\text { Act No. } 4\end{array}$ \\
\hline 2001 & & Preferential Procurement Policy Framework Regulations \\
\hline 2002 & & $\begin{array}{l}\text { Labour Relations Amendment Act } \\
\text { Basic Conditions of Employment Amendment Act }\end{array}$ \\
\hline 2003 & & $\begin{array}{l}\text { Skills Development Amendment Act } \\
\text { Broad-basedBlack Economic Empowerment Act No. } 53\end{array}$ \\
\hline 2007 & & B-BBEE Codes of Good Practice \\
\hline 2011 & & National Development Plan (2030) \\
\hline 2013 & & B-BBEE Amendment Act No. 46 \\
\hline 2014 & & $\begin{array}{l}\text { Basic Conditions of Employment Amendment Act } \\
\text { Employment Equity Amendment Act } \\
\text { Employment Equity Regulations }\end{array}$ \\
\hline 2015 & & $\begin{array}{l}\text { B-BBEE Revised Codes of Good Practice } \\
\text { Employment Services Act }\end{array}$ \\
\hline 2016 & & B-BBEE Regulations \\
\hline 2017 & & Preferential Procurement Policy Framework Regulations \\
\hline 2018 & & Proposed amendments to the Codes of Good Practice \\
\hline
\end{tabular}

Note: Please see full reference list of the article, Grobler, C., Van Wyk, R. \& Magau, M., 2019, 'Transformational change leadership framework for implementing Broad-Based Black Economic Empowerment in South African organisations', Acta Commercii 19(1), a686. https://doi.org/10.4102/ac.v19i1.686, for more information.

B-BBEE, Broad-Based Black Economic Empowerment.

FIGURE 1: Transformation statutes and timeline of enactment. 
from business. On 29 March 2018, two draft statements with further proposed amendments to the codes were gazetted for comment (Pillay \& Hannie 2018). The proposed changes to the skills development element are some of the most fundamental since the implementation of the 2013 Codes. On 15 June 2018, further proposed changes to the 2013 Codes were published for comment (Nkosi 2018). These changes focus on definitions and the enterprise and supplier development elements.

\section{The need for transformational change leadership}

Transformation in organisations needs to be systematic, and legal compliance is merely the start of the change process (Booysen 2007). The Revised Codes of Good Practice (2013) offers organisations a strategic transformation opportunity rather than a 'points-shopping exercise' (Vassan 2015:10). Many change management processes have been developed over the years. Change management involves the setting of a new vision, consultation with employees, leadership skills, commitment and the available resources for implementation (Hurn 2012; Kotter 1996). An integrated approach is required to drive methodical, productive change, mitigate barriers to change and address the consequences of the change (Al-Haddad \& Kotnour 2015). While change needs to be well managed, effective leadership will ensure that the change is successfully introduced and sustained (Gill 2002). There is a need for leadership to drive transformational change (Allio 2012; Kotter 1996). Change leadership as defined by Griffith-Cooper and King (2007:14) comprises 'a set of principles, techniques, or activities applied to the human aspects of executing change to influence intrinsic acceptance while reducing resistance'. Change leaders have inspired visions, are able to anticipate a new reality and how to achieve it. They understand how change is experienced by employees, ensure that employees are ready for and accept the change. Kotter's eight-step change leadership model is one of the most broadly recognised change management models (Pollack \& Pollack 2014). Kotter's (1996) proposed eight steps for leading change in organisations are:

Step 1: Establish a sense of urgency

Step 2: Form a powerful guiding coalition

Step 3: Create a vision

Step 4: Communicate the vision

Step 5: Empower others to act on the vision or broad-based change

Step 6: Plan for and create short-term wins

Step 7: Consolidate improvements and create still more change

Step 8: Institutionalise new approaches. (p. 61)

Many commonalities are found with Kotter's eight-step change leadership model and phases, steps or elements of other transformational change models. An integrated view of the comparable steps, elements and phases of the models is presented in Table 1. This indicates backing for the applicability of Kotter's change leadership model to drive transformational change.

\section{Method}

\section{Research philosophy and design}

The research philosophy is constructivism as the study aimed to understand numerous realities from several perspectives. Constructivism acknowledges that the researcher's knowledge, experience and bias impact his or her inferences.

A purposeful multiple qualitative case study research design was used. This was selected as most appropriate as it describes a phenomenon and the real-life context in which it occurred. The study commenced with a thorough literature review on transformational legislation and change leadership models. A transformed organisation was then defined to guide the identification of the target population. A purposive sample of 16 organisations was selected based on their rankings on the Top 100 Most Empowered Companies (Empowerdex 2016), and the study's definition of a transformed organisation. A ranking was carried out based on the companies' verified B-BBEE scores over a period of 3 years. The ranking of the 16 organisations from where participants hailed is contained in Table 2. Although the companies' information is available in the public domain, company names were not used because of ethical considerations. Participants were selected based on their position, knowledge and involvement in implementing B-BBEE. Participants were assigned a number based on the sequence of the interviews, and their positions generalised to ensure their anonymity. Informed consent was obtained from participants individually prior to any interviews conducted.

\section{Defining a transformed organisation}

A transformed organisation was defined as per the requirements of the Oliver Legends of Empowerment Award (Topco 2016) as an organisation that:

- makes an exceptional, sustained contribution to, and has an established reputation for driving transformation and implementation of strategic B-BBEE policies

- has a current, valid Level 4 B-BBEE certificate $(100 \%$ preferential procurement recognition)

- shows sustainable financial performance.

Reflexivity was engaged to approach the research openly, honestly, to improve rigour (Jootun, McGhee \& Marland 2009) and to prevent prior knowledge from distorting the researcher's perception of the data (McGhee, Marland \& Atkinson 2007). Reflexivity allows the researcher to provide a justification for his or her research decisions (Darawsheh 2014). 
TABLE 1: A comparison of other change leadership elements with Kotter's (1996) eight-step change leadership model.

\begin{tabular}{|c|c|c|c|c|c|c|c|c|}
\hline Source & $\begin{array}{l}\text { Drive and urgency } \\
\text { to change }\end{array}$ & Leading change & Creating a vision & $\begin{array}{l}\text { Communicating } \\
\text { the vision }\end{array}$ & $\begin{array}{l}\text { Employees taking } \\
\text { responsibility and } \\
\text { understand role in } \\
\text { implementation }\end{array}$ & Short-term gains & $\begin{array}{l}\text { Evaluation of } \\
\text { implementation }\end{array}$ & $\begin{array}{l}\text { Recreation of } \\
\text { vision and } \\
\text { institutionalisation }\end{array}$ \\
\hline Kotter (1996) & $\begin{array}{l}\text { Step 1: } \\
\text { Establish a sense of } \\
\text { urgency }\end{array}$ & $\begin{array}{l}\text { Step 2: } \\
\text { Create a guiding } \\
\text { coalition }\end{array}$ & $\begin{array}{l}\text { Step 3: } \\
\text { Develop a vision } \\
\text { and strategy }\end{array}$ & $\begin{array}{l}\text { Step 4: } \\
\text { Communicate the } \\
\text { change }\end{array}$ & $\begin{array}{l}\text { Step 5: } \\
\text { Empowering } \\
\text { others to act on } \\
\text { the vision }\end{array}$ & $\begin{array}{l}\text { Step 6: } \\
\text { Planning for and } \\
\text { creating } \\
\text { short-term wins }\end{array}$ & $\begin{array}{l}\text { Step 7: } \\
\text { Consolidating } \\
\text { improvements } \\
\text { and creating still } \\
\text { more change }\end{array}$ & $\begin{array}{l}\text { Step 8: } \\
\text { Institutionalising } \\
\text { new approaches }\end{array}$ \\
\hline Hall (1991) & $\begin{array}{l}\text { Commitment to } \\
\text { urgency, relevance } \\
\text { and excellence }\end{array}$ & - & $\begin{array}{l}\text { Element 1: } \\
\text { Creating a new or } \\
\text { redefining the } \\
\text { current vision }\end{array}$ & $\begin{array}{l}\text { Element 2: } \\
\text { Consistently and } \\
\text { continuously } \\
\text { communicating } \\
\text { the vision }\end{array}$ & $\begin{array}{l}\text { Element 3: } \\
\text { Employees taking } \\
\text { ownership in the } \\
\text { process of } \\
\text { change } \\
\text { Element 4: } \\
\text { Employees } \\
\text { understanding } \\
\text { their roles }\end{array}$ & - & $\begin{array}{l}\text { Element 5: } \\
\text { Evaluating the } \\
\text { implementation }\end{array}$ & $\begin{array}{l}\text { Element 6: } \\
\text { Recreating the } \\
\text { vision }\end{array}$ \\
\hline Judson (1991) & $\begin{array}{l}\text { Phase 1: } \\
\text { Analysis and } \\
\text { planning for change }\end{array}$ & - & - & $\begin{array}{l}\text { Phase 2: } \\
\text { Communicating } \\
\text { the change }\end{array}$ & $\begin{array}{l}\text { Phase 3: } \\
\text { Gaining } \\
\text { acceptance of } \\
\text { new behaviours }\end{array}$ & $\begin{array}{l}\text { Phase 4: } \\
\text { Change from the } \\
\text { status quo to the } \\
\text { required state }\end{array}$ & - & $\begin{array}{l}\text { Phase 5: } \\
\text { Consolidate and } \\
\text { institutionalise } \\
\text { the new state }\end{array}$ \\
\hline $\begin{array}{l}\text { Burke and } \\
\text { Litwin } \\
(1992: 531-532)\end{array}$ & $\begin{array}{l}\text { Environmental } \\
\text { interface - any } \\
\text { outside condition or } \\
\text { situation that } \\
\text { influences the } \\
\text { performance of the } \\
\text { organisation }\end{array}$ & $\begin{array}{l}\text { 'Leadership' is } \\
\text { executives } \\
\text { providing overall } \\
\text { direction and } \\
\text { serving as } \\
\text { behavioural role } \\
\text { models for all } \\
\text { employees }\end{array}$ & $\begin{array}{l}\text { What top } \\
\text { management } \\
\text { believe and } \\
\text { declared the } \\
\text { mission and } \\
\text { strategy and } \\
\text { what employees } \\
\text { believe is the } \\
\text { central purpose } \\
\text { of the } \\
\text { organisation }\end{array}$ & $\begin{array}{l}\text { Communicating } \\
\text { the mission and } \\
\text { strategy: Planned } \\
\text { culture change } \\
\text { aligned with } \\
\text { strategy and } \\
\text { leader behaviour }\end{array}$ & $\begin{array}{l}\text { What top } \\
\text { management } \\
\text { believe and } \\
\text { declared the } \\
\text { mission and } \\
\text { strategy and } \\
\text { what employees } \\
\text { believe is the } \\
\text { central purpose } \\
\text { of the } \\
\text { organisation }\end{array}$ & - & - & - \\
\hline $\begin{array}{l}\text { Kanter et al. } \\
\text { (1992) }\end{array}$ & $\begin{array}{l}\text { Phase 1: } \\
\text { Analyse the } \\
\text { organisation and } \\
\text { the need for } \\
\text { change; Separate } \\
\text { from the past } \\
\text { Phase } 4: \\
\text { Create a sense } \\
\text { of urgency }\end{array}$ & $\begin{array}{l}\text { Phase 5: } \\
\text { Support a strong } \\
\text { leader role } \\
\text { Phase 6: } \\
\text { Line up political } \\
\text { sponsorship }\end{array}$ & $\begin{array}{l}\text { Phase 2: } \\
\text { Create a vision } \\
\text { and common } \\
\text { direction }\end{array}$ & $\begin{array}{l}\text { Phase 9: } \\
\text { Communicate, } \\
\text { involve people } \\
\text { and be honest }\end{array}$ & $\begin{array}{l}\text { Phase 8: } \\
\text { Develop enabling } \\
\text { structures }\end{array}$ & $\begin{array}{l}\text { Phase 7: } \\
\text { Craft an } \\
\text { implementation } \\
\text { plan }\end{array}$ & - & $\begin{array}{l}\text { Phase 10: } \\
\text { Reinforce and } \\
\text { institutionalise } \\
\text { the change }\end{array}$ \\
\hline $\begin{array}{l}\text { Armenakis and } \\
\text { Bedeian (1999); } \\
\text { Armenakis and } \\
\text { Harris (2002) }\end{array}$ & $\begin{array}{l}\text { Individuals must } \\
\text { believe that things } \\
\text { are wrong that } \\
\text { require change: } \\
\text { 'burning platform'. } \\
\text { Compelling need for } \\
\text { change to be } \\
\text { enthused for } \\
\text { change }\end{array}$ & - & - & $\begin{array}{l}\text { High importance } \\
\text { need to be given } \\
\text { to change } \\
\text { communication } \\
\text { to convey the } \\
\text { nature of change }\end{array}$ & - & - & - & - \\
\hline Chapman (2002) & Reason for change & \multicolumn{2}{|c|}{$\begin{array}{l}\text { Visionary leadership from the chief } \\
\text { operations officer (CEO) }\end{array}$} & - & $\begin{array}{l}\text { The roles of } \\
\text { change agents }\end{array}$ & - & - & - \\
\hline
\end{tabular}

\section{Data collection}

Data sources included the published company annual integrated reports for the financial years ending in 2015 and 2016. As all the companies are listed on the Johannesburg Stock Exchange, reports were in public domain and easily accessible. The reports were perused thoroughly for references to B-BBEE or transformation as additional data for analysis. The document analysis commenced prior to the semi-structured interviews and served as input for the preparation for interviews.

An interview guide was prepared to ensure that the researcher addressed the same topics and asked the same questions in the same way in every interview. The literature review informed the formulation of the interview questions. The interview questions were not exhaustive, as the interviews were semi-structured, probing questions were posed for clarification or to obtain additional information.

Interviews were conducted first with four company participants. After conducting thematic analysis from the data collected through document analysis and the interviews, a peer-debriefing interview was held with an expert B-BBEE consultant. The peer-debriefing interview was conducted to gather additional data for triangulation, authentication and thereby enhance the credibility of the research findings (Golafshani 2003; Thomas \& Magilvy 2011). The participant biographic data are presented in Table 3. 
TABLE 2: Ranking of ideal participant organisations.

\begin{tabular}{|c|c|c|c|c|c|c|c|c|c|c|c|c|c|c|}
\hline \multicolumn{4}{|c|}{ Empowerdex ranking } & \multirow[t]{2}{*}{ Top company award } & \multirow{2}{*}{$\begin{array}{c}\text { Organisation } \\
\text { name }\end{array}$} & \multirow[t]{2}{*}{ Industry } & \multicolumn{4}{|c|}{ Recognition level } & \multicolumn{4}{|c|}{ Points } \\
\hline $\begin{array}{l}2016 \\
\text { RCOGP }\end{array}$ & $\begin{array}{l}2016 \\
\text { COGP }\end{array}$ & 2015 & 2014 & & & & $\begin{array}{l}2016 \\
\text { RCOGP }\end{array}$ & $\begin{array}{l}2016 \\
\text { COGP }\end{array}$ & 2015 & 2014 & $\begin{array}{l}2016 \\
\text { RCOGP }\end{array}$ & $\begin{array}{l}2016 \\
\text { COGP }\end{array}$ & 2015 & 2014 \\
\hline 2 & - & 1 & 1 & $\begin{array}{l}\text { Top Empowerment: } \\
\text { Top } 5 \text { Empowered } \\
\text { Companies Award } \\
2017\end{array}$ & Company 1 & Food producers & Level $2^{\mathrm{a}}$ & - & Level 2 & Level 2 & 97.82 & - & 98.39 & 95.17 \\
\hline 4 & - & 28 & $\dagger$ & - & Company 2 & $\begin{array}{l}\text { Equity investments } \\
\text { and instruments }\end{array}$ & Level $2^{\mathrm{a}}$ & - & Level 2 & Level 3 & 95.79 & - & 86.30 & 76.33 \\
\hline 5 & - & 3 & 7 & - & Company 3 & $\begin{array}{l}\text { Investment } \\
\text { insurance }\end{array}$ & Level $3^{a}$ & - & Level 2 & Level 2 & 92.82 & - & 94.58 & 89.44 \\
\hline 6 & - & 79 & $\dagger$ & - & Company 4 & Industrial goods & Level $4^{a}$ & - & Level 3 & Level & 87.30 & - & 75.45 & $\dagger$ \\
\hline 7 & - & 59 & 58 & $\begin{array}{l}2017 \text { Honorary } \\
\text { Award: Legends of } \\
\text { Empowerment }\end{array}$ & Company 5 & $\begin{array}{l}\text { Industrial goods } \\
\text { and services }\end{array}$ & Level $4^{a}$ & - & Level 3 & Level 3 & 83.56 & - & 79.42 & 75.54 \\
\hline 8 & - & - & 65 & - & Company 6 & Mining & Level $4^{a}$ & - & Level & Level 4 & 83.51 & - & - & 74.02 \\
\hline \multirow[t]{2}{*}{9} & - & 30 & $\dagger$ & - & Company 7 & Financial services & Level $4^{a}$ & - & Level 2 & $\dagger$ & 83.10 & - & 86.01 & $\dagger$ \\
\hline & 10 & 9 & 4 & - & Company 8 & $\begin{array}{l}\text { Industrial goods } \\
\text { and services }\end{array}$ & - & Level 2 & Level 2 & Level 2 & - & 90.91 & 91.15 & 92.00 \\
\hline 10 & - & 41 & 38 & $\begin{array}{l}2017 \text { Honorary } \\
\text { Award: Legends of } \\
\text { Empowerment }\end{array}$ & Company 9 & Healthcare & Level $4^{a}$ & & Level 3 & Level 3 & 82.33 & - & 83.58 & 79.18 \\
\hline 11 & - & 56 & 70 & - & Company 10 & $\begin{array}{l}\text { Containers and } \\
\text { packaging }\end{array}$ & Level $4^{\mathrm{a}}$ & - & Level 3 & Level 4 & 81.67 & - & 79.62 & 71.64 \\
\hline 12 & - & 43 & 31 & - & Company 11 & $\begin{array}{l}\text { Pharmaceuticals } \\
\text { and biotechnology }\end{array}$ & Level $4^{\mathrm{a}}$ & - & Level 3 & Level 3 & 81.52 & - & 83.29 & 81.73 \\
\hline 13 & - & & $\dagger$ & - & Company 12 & $\begin{array}{l}\text { Industrial } \\
\text { engineering }\end{array}$ & Level $4^{\mathrm{a}}$ & - & Level 3 & $\dagger$ & 80.41 & - & 79.56 & $\dagger$ \\
\hline 14 & - & 67 & $\dagger$ & - & Company 13 & $\begin{array}{l}\text { Publishing and } \\
\text { printing }\end{array}$ & Level $4^{\mathrm{a}}$ & - & Level 3 & $\dagger$ & 80.04 & - & 76.24 & $\dagger$ \\
\hline 15 & - & 38 & 27 & - & Company 14 & Support services & Level $5^{a, b}$ & - & Level 3 & Level 3 & 80.95 & - & 84.12 & 84.18 \\
\hline \multirow[t]{2}{*}{22} & - & 11 & 15 & - & Company 15 & Healthcare & Level $8^{a, b}$ & - & Level 2 & Level 2 & 63.28 & - & 90.85 & 87.82 \\
\hline & 16 & 18 & 26 & - & Company 16 & $\begin{array}{l}\text { Industrial goods } \\
\text { and services }\end{array}$ & - & Level 2 & Level 2 & Level 2 & - & 88.93 & 88.93 & 85.00 \\
\hline
\end{tabular}

COGP, Codes of Good Practice; RCOGP, revised codes of good practice.

Note: $\uparrow$, indicates organisations not ranked in 2014.

a, measured under RCOGP.

b, discounted a level under RCOGP.

Table 3: Participant biographic data.

\begin{tabular}{lclllll}
\hline Industry & Participant & Position & Race & Gender & Age & Qualifications \\
\hline Industrial goods and services & 1 & Executive & Mixed race people & Female & 45 & Master's degree \\
Investment insurance & 2 & Executive & White people & Female & 49 & Master's degree \\
Food producers & 3 & Executive & Black people & Female & 37 & Executive development programme \\
Financial services & 4 & Top management & White people & Female & 35 & Bachelor's degree, postgraduate diploma \\
Consulting & 5 & Executive & White people & Male & 50 & PhD \\
\hline
\end{tabular}

The interview questions were intended to answer the main research and sub-questions. Questions 1,4 and 5 explored perceptions of the dynamics in play in implementing B-BBEE providing input to sub-question 1. Questions 6-12 aimed to establish whether organisations used formal change management models for the implementation of B-BBEE. Questions 5-9 specifically included questions on Kotter's change leadership model steps. For example, question 6.1 'Do you have a formal structure, organisation or department in place to manage transformation or B-BBEE in your organisation?' was aimed at verifying whether Kotter's Step 2: Establish a guiding coalition, had been implemented.

\section{Data analysis}

Thematic analysis, a foundational qualitative method of analysis (Braun \& Clarke 2006), compatible with constructivism was applied. The method was selected because of its flexibility and potential to provide a rich, detailed and complex account of data. It enables the identification, analysis and reporting of themes or patterns within data (Boyatzis 1998). Thematic analysis organises and describes the data set in rich detail and interprets several facets of the research topic.

A deductive approach using Kotter's change leadership steps and additional elements from other models as interpretive framework was used. The data were sorted under the various pre-defined themes. An inductive perspective was applied when new insights or discoveries were made. The linking of the two approaches was not an overwhelming task as the relevant concepts were in the reach of the researcher's own knowledge and research.

\section{Trustworthiness}

The research method was described in detail to ensure trustworthiness. All data collected are available for inspection 
and stored in both hard copy format and electronically in a password-protected cloud server. The data were reported in a self-reflective manner and a research journal was kept.

\section{Ethical considerations}

Ethical clearance was provided by the College of Business and Economics, University of Johannesburg (ethical clearance number: FOM2016IPPM048). All information was treated according to the ethical rules and guidelines of the University of Johannesburg. Participants signed an informed consent form, and anonymity and confidentiality were assured. Interview transcriptions were kept safely with an electronic password.

\section{Findings}

The findings are reported in four sections: the first three aligned with the study objectives and the final section on emergent themes or elements discovered.

\section{The nature of transformational requirements on South African businesses}

The findings indicated that:

- The legal framework for the implementation of transformation was complex, and the constant changes in legislative requirements led to frustration:

'You can't keep chopping and changing. One day, the one thing is okay, and the next day, it's not. And that is where business is actually frustrated. It does not help the cause. If you are already aggravated about BEE just to start off with, all these changes and uncertainties around it just makes it worse.' (Participant 1)

- The newly introduced Economically Active Population targets presented compliance challenges under the Management Control and Skills Development elements. Challenges related to employee demographics and the Skills Development spend target (6\% of annual payroll) within budgetary constraints:

'Skills, by far, ... especially from the measurements that went up from $3 \%$ to $6 \%$. It is a lot harder for use to get to the skills spend that they require, because our employee base is so big.' (Participant 4).

- There was a sense of frustration with government because of a perceived lack of national leadership and vision. Seemingly different transformation agendas existed in different government departments, and requirements changed constantly. There appeared to be inconsistent recognition of B-BBEE scorecard levels in public procurement:

'We have to really work very hard to do well on the BEE score, and the government takes it into account quite strongly in regard to licences, but, for many other things, you know, it does not actually give us the advantage that it should.' (Participant 2)

- The B-BBEE scorecard system employed a punitive approach, and failed to recognise or incentivise businesses for doing the right things.

\section{The use of change management models for the implementation of Broad-Based Black Economic Empowerment}

None of the organisations studied applied formal change management models in strategically implementing B-BBEE. Statements included 'It was not implemented formally' (Participant 1), 'I think they made up their own. They were pioneering' (Participant 2). Organisations acknowledged that a formal change management approach could result in implementing more sustainable transformation: 'It is a continuous learning process. Every time, we learn to do things smarter' (Participant 3).

\section{The use of Kotter's eight-step change leadership model for the implementation of Broad-Based Black Economic Empowerment in South African businesses}

Findings indicated that organisations applied many, if not all, of Kotter's steps in implementing B-BBEE intuitively. The findings are presented using Kotter's (1996) eight steps as interpretive framework.

\section{Step 1: Establish a sense of urgency}

Kotter (1996) argues that a strong sense of urgency, as a result of an established need for change, is essential for organisational change to commence. Various drivers for change were established: strategic imperatives, economic sustainability, customer requirements, good corporate citizenship and corporate leadership: 'He knew that Black Economic Empowerment was going to be very strategic going forward' (Participant 1). A sense of urgency existed to ensure that the appropriate B-BBEE recognition levels were attained, maintained or improved upon mostly driven by the drivers for change cited: 'Through Preferential Procurement, there's an explicit intent to drive a sense of urgency' (Participant 5), 'There has always been a sense of urgency' (Participant 3).

It was concluded that Kotter's Step 1 was relevant in the implementation of B-BBEE, both in terms of identifying the driver for change and creating the sense of urgency.

\section{Step 2: Forming a powerful guiding coalition}

Kotter's (1996) second step is creating a powerful guiding coalition to drive the change. The majority of organisations reported some form of a guiding coalition, for example 'A transformation unit that was directly under the leadership of the CEO' (Participant 3). All the participants, holding executive leadership roles, met Kotter's (1996) requirements of position power, expertise, credibility and leadership. Organisations had various structures, from part-time B-BBEE coordinators, divisional management responsibility, to a full-time B-BBEE function or department. Strong top management support over and above the guiding coalition was critical to the success of the implementation of B-BBEE: 'It is not possible to implement the kind of things that we 
implement without there being full involvement from management' (Participant 2). It can be inferred that Step 2 of Kotter's (1996) change leadership model can be applied in driving the implementation of B-BBEE. The form of the coalition could be adjusted based on the organisational structure and culture.

\section{Step 3: Creating a vision}

Setting a clear vision for the transformation initiative is the first task of the guiding coalition (Kotter 1996:70). This should create cohesion in efforts to attain the vision. The study found various stages of vision creation. Visions varied from none, to scorecard level targets, vague statements on achieving transformation, to very clear transformation vision and strategies, for example, 'It is one of our key focus areas, one of our five strategic objectives' (Participant 3). Where clear strategies existed, these were integrated in the overall business strategy of the organisations: 'It is such an integrated part of what we do' (Participant 3), 'There is no such thing as a transformation strategy. It is the strategy of the business and the degree to which that strategy is understood positively' (Participant 5). Based on the findings, it seems that Kotter's Step 3 could be valuable in the implementation of B-BBEE.

\section{Step 4: Communicate the change vision}

Communicating the change vision is an important step in Kotter's (1996) model. The significance of communicating the change vision, the reason for change and the change method is confirmed by many authors (Battilana et al. 2010; Franklin 2014; Judson 1991; Kanter, Stein \& Jick 1992). In the majority of cases studied, the organisations' overall transformation vision or strategy was not communicated to the organisation: 'We actually don't have one [strategy to communicate], but we should' (Participant 1). The importance of communicating the transformation vision was recognised. In one case, the transformation strategy was contained in the organisation's strategy document. It was posted on the organisation's website, and shared annually in strategy cascading sessions and newsletters: 'So, there are various forums where we gather our employees, and we use those platforms to share our progress' (Participant 3 ). The findings indicated that the level and method of communication of the transformation vision, strategy or objectives should be appropriate to the audience: 'The average employee does not want to know all the technical nonsense of this' (Participant 5). This would indicate that Kotter's (1996) Step 4 could constitute an important step in the implementation of B-BBEE.

\section{Step 5: Empowering others to act on the vision or broad-based change}

Kotter (1996) recognises that communicating the change vision in itself does not translate into action. He suggests that obstacles be removed, structures and systems changed, increasing supervisors' competence and training in general. The findings indicated three levels of empowerment: basic awareness: 'At holding company level, people are very much aware' (Participant 2), training on the 2013 B-BBEE Codes of Good Practice and involvement in the implementation of B-BBEE: 'At the subsidiaries, they also need to be heavily involved' (Participant 2). An insightful finding was that managers and employees acted whether they were explicitly empowered or not. Their world views impacted their decisions and actions which positively or negatively impacted transformation. The level of empowerment to drive transformation was dependent on the knowledge, position and transformation maturity of the organisation. In certain cases, employees and managers were empowered to act and then held accountable for their actions in driving transformation: 'Then it is holding the business accountable, tracking, monitoring, visibly holding people accountable' (Participant 3). Step 5 of Kotter's (1996) model seems to be particularly important in the successful implementation of B-BBEE. Every employee has an impact on the success or failure of transformation.

\section{Step 6: Planning for and creating short-term wins}

To show the viability of the change, Kotter (1996) advocates short-term wins that support the achievement of the longer term change goals. Opportunities for rewarding those implementing change and the celebration of achieving milestones also assist to maintain the momentum for change. This approach was corroborated by the expert B-BBEE consultant:

'It is imperative not only to celebrate our successes, actually design successes into the change process early on, to sustain the momentum and, therefore, where there are successes, celebrate them, so people can see visibly that we keep the tyres on. It's working.'

No clear evidence could be found from the study that transformation strategies or plans included specific shortterm milestones. Because of the annual external B-BBEE compliance verification, organisations did compare achievements against the previous scorecard. Improvements were communicated, and in some instances celebrated: 'When we achieved the Level3, we opened a couple of bottles of champagne after the meeting, and this year we did even better... I guess we do celebrate' (Participant 2). Only half of the respondents confirmed that they celebrated achievements and awards. There is opportunity to improve the momentum for transformation through the application of Step 6 of Kotter's model.

\section{Step 7: Consolidating improvements and creating more change}

Kotter (1996) argues that leaders need to provide evidence that change is working. He states that new processes can regress, and therefore that unsupportive policies, structures and systems be changed. Employees who can assist in driving the change should be recruited. He argues that the change process needs to be invigorated with new projects, themes or change agents to maintain the momentum for change. It seems that with B-BBEE, 'more change' is created externally through legislative changes, which necessitates a revised 
response from organisations. The findings indicated that organisations recognised the need for continued efforts to implement B-BBEE and transformation: 'This is like a major effort for the company, and we know it is not something that stops because we got a specific level and now it stops' (Participant 2).

Monitoring and measuring compliance and progress against B-BBEE provides evidence of transformation working in the organisation. All cases in the study reported on B-BBEE extensively at the highest levels of the organisations: 'Twice a year, it gets presented at the SETCom, a board subcommittee' (Participant 3). The frequency of monitoring and reporting varied between monthly and quarterly: 'We've got the Transformation Forum; they meet on a quarterly basis' (Participant 3). The verification audits happened annually. Non-achievement of targets or inadequate progress provided opportunity for new activities or interventions to be implemented to ensure compliance and progress on the transformation strategy. Step 7 of Kotter's model seems applicable, with the addition of measuring and monitoring of progress, and implementing corrective action, in the successful implementation of B-BBEE.

\section{Step 8: Institutionalising new approaches}

According to Kotter, there are two critical factors for the institutionalisation of transformation in organisational culture: firstly, demonstrating to employees how changes in approaches, behaviours and attitudes have resulted in improved performance, and, secondly, that the new approach needs to be embodied in the next generation of management (Kotter 1996:67). The cases support the need for institutionalising new approaches in as far as it affects B-BBEE: 'It is to run it as part of business; it must not be a standalone thing' (Participant 3). The findings indicate the need to continuously revisit the transformation vision, strategies and plans. New behaviours need to be entrenched into the day-to-day operation of the business:

'So, it is what you do day to day, in the business, just putting it in that context to say, "I got a target, and I got a milestone to achieve. So how do I do what I do every day with a transformation perspective on it?".' (Participant 3)

Step 8 seems to be relevant for the successful implementation of B-BBEE.

The study established that all of the steps in Kotter's eightstep change leadership model were applicable to some extent. Kotter's (1996) model could potentially be used as a transformational change leadership framework for the successful implementation of transformational B-BBEE in South African businesses.

\section{Themes additional to Kotter's eight steps \\ Commitment to transformation}

The findings indicated that for successful, sustainable transformation leadership commitment to transformation was paramount. Ten per cent of the participant companies proclaimed their commitment to transformation or B-BBEE publicly in their annual integrated reports. It was also confirmed by participants: '[Group] has always been committed in driving transformation' (Participant 3). A key finding was the significance of the personal conviction, values, beliefs, willpower and intent of leadership in driving transformation:

'One of my bosses at [company] said, "empowerment happens because you want it to", and I have never forgotten that. It is actually something, it is all about your intent.' (Participant 2)

These leaders viewed transformation beyond the borders of their organisation, for the greater good of South Africa.

\section{Leadership styles, traits or competencies to drive successful transformation}

The findings suggest that transformation starts with leadership, leaders' commitment and visibly setting the transformation vision and direction: 'It starts with leadership and the degree to which leadership sculpts clear direction that they personally believe in and are committed to' (Participant 5).

Specific leadership styles, traits or competencies may be required to lead sustainable transformation. Examples of statements from participants include:

'It is going to take a different generation of leader that is more open-minded, that is more culturally aware, so you are actually more in touch with the people of your country, and, outside, obviously globally astute.' (Participant 1 )

'Some are more culturally flexible and fit, but I would put it as a key attribute of a good leader' (Participant 5).

\section{The change locus of control}

A noteworthy finding is the interrelationship between the origin or nature of the driver for transformational change, the time frame and the level of planning and implementation of B-BBEE. The findings suggest that if the driver for implementing B-BBEE relates to customer demands or scorecard compliance pressure, and a limited time period to comply, organisations may react tactically to address the immediate pressure with no long-term sustainability. Conversely, if there is a deep desire from within the organisation to transform, driven by leadership with personal conviction, values and belief in the greater good of economic and social transformation, planning and interventions would be longer term, strategic and focused on sustainability:

'There is a convergence of forces that are needed to make change sticky and to make it meaningful from transformation perspective. A key facet of those forces is the degree to which the organisation is not responding to Client Scorecard pressure, but is expressing a deep desire for doing things differently.' (Participant 5)

The interrelationship is graphically illustrated in Figures 2 and 3 . 


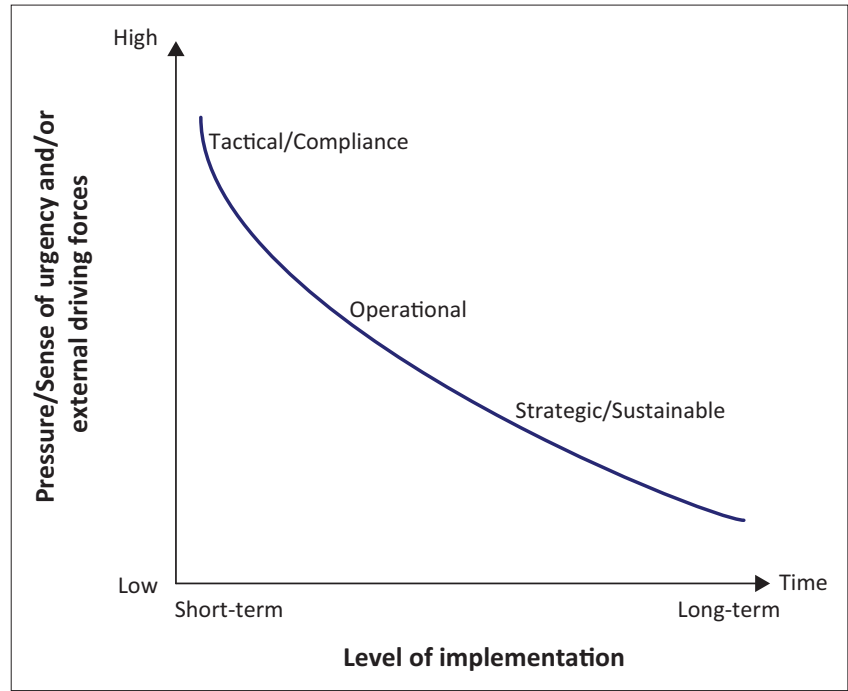

FIGURE 2: Influence of external driving forces on level and time frame of implementation.

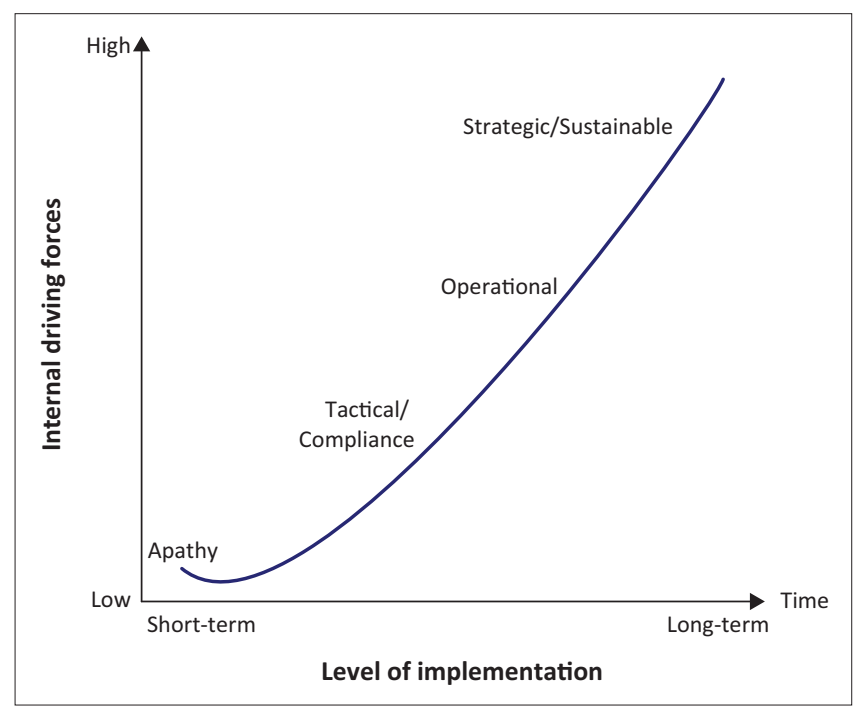

FIGURE 3: Influence of internal driving forces on level and time frame of implementation.

\section{The impact of organisational culture on transformation}

The findings support the literature purporting the requirement for a change in organisational culture to support organisational transformation (Burke \& Litwin 1992; Thomas \& Robertshaw 1999): 'How you approach everything in relation to your business, including BEE, is determined by the culture of the organisation' (Participant 1). The change management process to implement B-BBEE should be designed to assist individuals to adapt to the culture change:

'The stickiness of the initiatives requires a wider exposure, involvement and culture impact, because, at the heart of sustainable transformation is a reduction of social distance and improvement of a culture of inclusion.' (Participant 5)

It is important that leaders take ownership of change to ensure sustainable transformation: 'Anything is important in the organisation if the leadership sees it as important' (Participant 4).

\section{Complexity of transformation}

It was not surprising that the findings indicated high levels of complexity in the implementation of B-BBEE and transformation. Various issues were cited regarding legislative requirements, historical influences, cultural distance, frustrations, fear and negativity and different realities and world views: 'It is complex, unnecessarily so, because we don't have enough internal catalysts for change, we get over-dominated by external catalysts for change' (Participant 5).

\section{Setting targets, incentivising and rewarding transformation}

In certain cases, targets or key performance indicators were set on organisation level, and, in others, on individual level. In some cases, although targets were set, achievement of the targets was not incentivised, and non-achievement did not impact reward:

'We don't really have a formalised process like that, but ... I know what I am responsible for. One of my responsibilities is to absolutely critically look after our BEE level .... and I do, and I can tell you that, if I failed around the BEE, I would be very clear that I would not be doing my job, and that there would be consequences of that. So, we don't have like a formal KPI system, but, absolutely, it is the performance that is required from me.' (Participant 2)

In other cases, performance-based rewards were in place to reward achievement on transformation targets. In one case, non-achievement of transformation targets was penalised: 'You have a KPI on transformation, and if you don't perform, obviously, your overall performance rating goes down. If you perform well, it will also affect that as well' (Participant 3). Although it was common practice to include change targets in management's key performance indicators, the manner and duration of the reward system should be carefully considered:

'It's very normal for people to get rewarded in their KPAs for supporting any change process, and I would not exempt transformation from that. It is just a strategic change process like any other. But one has to be careful how strongly you pull that lever and for how long, because, if that is all you do, when you stop pulling the lever, the whole process collapses. So, it is appropriate to some degree, for some duration.' (Participant 5)

\section{Women leaders in transformation}

A study conducted by Chandler (2011) established that women exhibited more transformational, participative and inclusive leadership styles than men. In 12 of the 16 purposively sampled companies, the executive or senior manager responsible for transformation, B-BBEE and/or human resources were women. Four of the participants who took part in the study were women. Only the expert B-BBEE consultant interviewed was a man. In one case, it was stated that $80 \%$ of the Group B-BBEE Panel were women. 


\section{Towards a transformational change leadership framework for implementing Broad-Based Black Economic Empowerment}

This study established that Kotter's (1996) eight-step change leadership model could be applied in the implementation of B-BBEE. However, the findings indicate that additional elements are required for the successful, sustainable implementation of B-BBEE or transformation in organisations. Some are already included in the change leadership models reviewed, and some elements emerged from the study and were confirmed by the literature. The discoveries and findings have been included in the original integrated change model steps, elements and phases to indicate overlap and addition to current elements. Steps or elements not confirmed by the study have been excluded.

The elements of the transformational change leadership framework for the implementation of B-BBEE are described next.

\section{Element 1: Establish the need for change and the organisation's transformation maturity}

The first step is to acknowledge the organisation's transformation maturity, and then to establish and understand the drivers of change - external and internal - and understand their impact in planning the change. Internal versus external drivers for change could result in different levels of planning for and implementing change. The vision may differ based on whether the need for change is mere compliance or to implement sustained organisational transformation. For the description of the remainder of the elements, the proposed framework assumes an internal recognition that there exist a need for change and a desire to implement transformational change in the organisation.

\section{Element 2: Leadership, leadership commitment, vision and direction}

This step entails action by leadership from the top management in the organisation. The leaders individually and in a guiding coalition need to commit to transformation, create a compelling transformation vision, set the direction and serve as behavioural role models in leading the transformation (Burke \& Litwin 1992; Chapman 2002; Kanter et al. 1992; Kotter 1996). Leaders need to personally demonstrate commitment, conviction, values, beliefs, willpower and intent to drive transformation. Leaders need to motivate, build teams and create a culture of inclusion.

The establishment of a structure along the requirements of Kotter's Step 2: Create a guiding coalition forms part of this element. The transformation coalition should be aligned with the organisational structure and culture. The coalition should be mandated to implement transformation.

\section{Element 3: Creating a transformation vision integrated with the overall business strategy}

Leaders create the transformation vision and integrate it into the overall business strategy. The vision should ensure that transformation is integrated into the day-to-day business, and not seen as a separate project.

\section{Element 4: Management commitment, involvement and support}

Top management needs to visibly support the transformation vision and strategy. The requirement of top management support is also posited by Burke and Litwin (1992) and Thomas and Robertshaw (1999). Members of top management should be the role models for transformation. This top management support is required over and above leadership from the guiding coalition for successful transformation.

\section{Element 5: Create a culture supportive of the transformation strategy}

Leaders play a significant role in creating the culture and climate to drive transformation. Leaders should focus on creating a culture of inclusiveness, and harness the power of diversity. Values should be set and required behaviours established to drive a culture that is supportive of transformation. Employees should be encouraged to participate in transformation efforts, and should be recognised for living the transformation values and demonstrating the required behaviours.

\section{Element 6: Communication of the transformation vision as part of overall business strategy}

Communication of the transformation vision as part of the overall business strategy is crucial. The communication needs to be planned carefully to ensure that the right message is targeted at the right audience. The overall transformation vision needs to be communicated to all employees. Specialised or detailed technical communication should be reserved for employees directly involved in areas that require transformation.

\section{Element 7: Employee awareness, engagement, involvement and understanding their roles in implementing the transformation vision}

It is recognised that various levels of awareness, engagement, involvement and understanding of the transformation vision are required in an organisation. These levels relate to employees' role in implementing the transformation strategy. All employees require a basic awareness of the elements that make up B-BBEE and the overall objectives of the legislation. Employees should be trained in diversity and inclusion. Training should ensure that all employees positively engage in transformation and assist in creating a culture of inclusion. Specific departments or employees need to be trained on the technical requirements of the various elements and how they can contribute to reaching the targets and requirements. Employees should be rewarded to demonstrate the transformation values. 


\section{Element 8: Short-term wins and celebration of success}

In support of Kotter's (1996) Step 6: Planning for and creating short-term wins, the transformation plan needs to be designed to include milestones or short-term achievable targets that will be celebrated. Short-term wins demonstrate progress and assist in maintaining momentum in the implementation of transformation. Successes need to be recognised and celebrated in the organisation.

\section{Element 9: Evaluate implementation, monitor progress against the transformation vision and plan and recreate and institutionalise the transformation}

Progress on the transformation plan, over and above the B-BBEE scorecard, needs to be monitored regularly. Progress should be reported to top management and shared in the organisation. Areas for improvement need to be identified, whereafter strategies should be revisited and new activities or interventions implemented, to ensure continuous progress. The organisation should recognise changes in values, attitudes and behaviours that drive transformation and support the transformation vision and strategy, in order to further drive the change in organisational culture.

\section{Conclusion}

The study set out to determine whether a transformational change leadership framework could be applied in implementing the transformation intended by the $B-B B E E$ $A c t$, and to what extent Kotter's eight-step change leadership model could be applied in this regard. Despite the onerous requirements, challenges and complexity of B-BBEE legislation, none of the organisations studied applied any formal change management process for implementation. A need for a formal approach was established. All eight steps of Kotter's model, as well as some elements of the other change models reviewed, could be applied to ensure more successful implementation. Key discoveries include the significance of the role of leadership; leaders' personal commitment, values and beliefs; and top management's support in driving effective transformation. The effect of culture and climate on the sustainability of change, understanding the change locus of control and transformation maturity and its impact on the sustainability of transformation emerged as important considerations. These elements contributed to the conceptualisation of the transformational change leadership framework for the implementation of B-BBEE.

The elements of the framework are suggested as fundamentals for the successful implementation of B-BBEE. Therefore, it is recommended that, prior to embarking on any transformation journey, organisations should establish their transformation maturity and driver for change. The role of strong, visible leadership, coupled with their true personal commitment to transformation, should not be underestimated. The impact of organisational culture and climate, organisational values and the recognition of changed behaviours on the sustainability of change should also be recognised. The creation of a culture of inclusion is highly encouraged, and the importance of planning for short-term wins and integration into the overall business strategy needs to be carefully considered.

The influencing effect of leadership on culture, and that of organisational culture on transformation, the role of women leaders in transformation and the practical testing of the proposed framework create opportunities for further study.

Kotter's eight-step change leadership model, with cognisance of the proposed transformational change leadership framework elements, could guide the design of a change leadership programme for the more successful implementation of B-BBEE in South African organisations.

\section{Acknowledgements Competing interests}

The authors declare that they have no financial or personal relationships that may have inappropriately influenced them in writing this article.

\section{Authors' contributions}

C.G. was the student responsible for compiling the research. Both R.v.W. and M.D.M. made conceptual contributions.

\section{References}

Al-Haddad, S. \& Kotnour, T., 2015, 'Integrating the organizational change literature A model for successful change', Journal of Organizational Change Management 28(2), 234-262. https://doi.org/10.1108/JOCM-11-2013-0215

Allio, R., 2012, 'Leaders and leadership - Many theories, but what advice is reliable?', Strategy \& Leadership 41(1), 4-14. https://doi.org/10.1108/10878571311290016

Armenakis, A.A. \& Bedeian, A.G., 1999, 'Organizational change: A review of theory and research in the 1990s', Journal of Management 25(3), 293-315. https://doi .org/10.1016/S0149-2063(99)00004-5

Armenakis, A.A. \& Harris, S.G., 2002, 'Crafting a change message to create transformational readiness', Journal of Organizational Change Management 15(2), 169-183.

Arya, B. \& Bassi, B., 2009, 'Corporate social responsibility and broad-based Black Economic Empowerment legislation in South Africa - Codes of Good Practice', Business \& Society 20(10), 1-21. https://doi.org/10.1177/0007650309332261

Battilana, J., Gilmartin, M., Sengul, M., Pache, A.C. \& Alexander, J.A., 2010, 'Leadership competencies for implementing planned organizational change', Leadership Quarterly 21(3), 422-438. https://doi.org/10.1016/j.leaqua.2010.03.007

Booysen, L., 2007, 'Barriers to employment equity implementation and retention of blacks in management in South Africa', South African Journal of Labour Relations 31(1), 47-71.

Boyatzis, R.E., 1998, Transforming qualitative information: Thematic analysis and code development, Sage, Thousand Oaks, CA.

Braun, V. \& Clarke, V., 2006, 'Using thematic analysis in psychology', Qualitative Research in Psychology 3(2), 77-101. https://doi.org/10.1191/1478088706qp063 oaBurke, W.W. \& Litwin, G.H., 1992, 'A causal model of organizational performance and change', Journal of Management 18(3), 523-545. https://doi.org/10 .1177/014920639201800306

Chandler, D., 2011, 'What women bring to the exercise of leadership', Journal of Strategic Leadership 3, 1-12.

Chapman, J.A., 2002, 'A framework for transformational change in organisations', Leadership \& Organization Development Journal 23(1/2), 16-25. https://doi.org /10.1108/01437730210414535

Cronje, F., 2015, 'Why white South Africa must not turn its back on transformation Daily Maverick', Daily Maverick, 08 September, South Africa, viewed 05 March 2016, from https://www.dailymaverick.co.za/opinionista/2015-09-08-why-white -south-africa-must-not-turn-its-back-on-transformation/\#.WJVmQFV950x.

Darawsheh, W., 2014, 'Reflexivity in research: Promoting rigour, reliability and validity in qualitative research', International Journal of Therapy and Rehabilitation 21(12), 560-568. https://doi.org/10.12968/ijtr.2014.21.12.560 
Denton, M. \& Vloeberghs, D., 2003, 'Leadership challenges for organisations in the New South Africa', Leadership \& Organization Development Journal 24(2), 84-95. https://doi.org/10.1108/01437730310463279

Empowerdex, 2016, Top 100 most empowered companies, viewed 13 May 2017, from http://www.empowerdex.com.

Emuze, F. \& Adlam, R., 2013, 'Implementation of Broad-Based Black Economic Empowerment in construction : A South African metropolitan area study : Review article', Acta Structilia : Journal for the Physical and Development Sciences 20(1), 126-154.

Franklin, M., 2014, '3 lessons for successful transformational change', Industria and Commercial Training 46(7), 364-370. https://doi.org/10.1108/ICT-04-2014 0027

Gill, R., 2002, 'Change management-or change leadership?', Journal of Change Management 3(4), 307-318. https://doi.org/10.1080/714023845

Golafshani, N., 2003, 'Understanding reliability and validity in qualitative research', The Qualitative Report 8(4), 597-607.

Griffith-Cooper, B. \& King, K., 2007, 'The partnership between project management and organizational change: Integrating change management with change leadership', Performance Improvement 46(1), 14-20. https://doi.org/10.1002/pfi.034

Hall, L.W., 1991, 'Six elements for implementing and managing change', Logistics Information Management 6(2), 46-48.

Horwitz, F.M. \& Jain, H., 2011, 'An assessment of employment equity and Broad Based Black Economic Empowerment developments in South Africa', Equality, Diversity and Inclusion: An International Journal 30(4), 297-317. https://doi.org/10.1108/ 02610151111135750

Hurn, B.J., 2012, 'Management of change in a multinational company', Industrial and Commercial Training 44(1), 41-46. https://doi.org/10.1108/00197851211193417

Jootun, D., McGhee, G. \& Marland, G.R., 2009, 'Reflexivity: Promoting rigour in qualitative research', Nursing Standard 23(23), 42-46. https://doi.org/10.7748/ ns2009.02.23.23.42.c6800

Judson, A.S., 1991, Changing behaviour in organisations: Minimizing resistance to change, Blackwell, Cambridge, MA.

Kanter, R.M., Stein, B. \& Jick, T., 1992, The challenge of organizational change: How companies experience it and leaders guide it, Free Press, New York, NY.

Knowledge Resources \& Mandate Molefi HR Consultants, 2016, National survey on transformation, diversity and inclusion 2016, KR Publishing (Pty) Ltd., Randburg.

Kotter, J.P., 1996, Leading change, Harvard Business School Press, Boston, MA.

Krüger, L.P., 2011, 'The impact of black economic empowerment (BEE) on South African businesses: Focusing on ten dimensions of business performance', Southern African Business Review 15(3), 207-233.

Krüger, L.P., 2014, 'South African managers' perceptions of black economic empowerment (BEE): A 'sunset' clause may be necessary to ensure future sustainable growth', Southern African Business Review 18(1), 80-99.

Leonard, A. \& Grobler, A.F., 2006, 'Exploring challenges to transformational leadership communication about employment equity: Managing organizational change in South Africa', Journal of Communication Management 10(4), 390-406. https:// doi.org/10.1108/13632540610714827

McGhee, G., Marland, G.R. \& Atkinson, J., 2007, 'Grounded theory research: Literature reviewing and reflexivity', Journal of Advanced Nursing 60(3), 334-342. https:// doi.org/10.1111/j.1365-2648.2007.04436.x

National Planning Commission, 2011, National Development Plan (2030), Department, The Presidency, Republic of South Africa, Pretoria.

Nkosi, M., 2017, Re-thinking transformation policy and strategy, Transcend Resource Centre, viewed 20 July 2017, from http://www.transcend.co.za/resource-centre/ blog/transcend/re_thinking_transformation_policy_and_strategy.html.

Nkosi, M., 2018, New BEE legislation - Further amendments to the Codes of Good Practice, Transcend Resource Centre, viewed 18 June 2018, from https://www. transcend.co.za/new-bee-legislation-further-amendements-to-the-codes-ofgood-practice-15-june-2018/.

Padayachy, Y., 2016, 'The origin and context of the B-BBEE Act', in B-BBEE Commission (ed.), The whistle - You are on the right track, pp. 6-8, B-BBEE Commission, Pretoria.

Pillay, V. \& Hannie, A., 2018, 'Unpacking the fundamentals: Proposed changes to the BEE codes', Black Economic Empowerment Alert 4, 1-5.
Pollack, J. \& Pollack, R., 2014, 'Using Kotter's eight stage process to manage an organisational change program: Presentation and practice' Systemic Practice and Action Research 28, 51-66. https://doi.org/10.1007/s11213-014-9317-0

South African Government, 1993, The Interim Constitution of South Africa, Government Gazette No. 15466, Government Printing Works, Pretoria.

South African Government, 1994, Restitution of Land Rights Act, Government Gazette No. 17804, Government Printing Works, Pretoria.

South African Government, 1995, Labour Relations Act, Government Gazette No. 16861, Government Printing Works, Pretoria.

South African Government, 1996, The Constitution of South Africa, Government Gazette No. 17678, Government Printing Works, Pretoria.

South African Government, 1997, Basic Conditions of Employment Act, Government Gazette No. 18491, Government Printing Works, Pretoria.

South African Government, 1998a, Employment Equity Act, Government Gazette No. 19370, Government Printing Works, Pretoria.

South African Government, 1998b, National Empowerment Fund Act, Government Gazette No. 19589, Government Printing Works, Pretoria.

South African Government, 1998c, Skills Development Act, Government Gazette No. 19420, Government Printing Works, Pretoria.

South African Government, 1999, Skills Development Levies Act, Government Gazette No. 19984, Government Printing Works, Pretoria.

South African Government, 2000a, Preferential Procurement Policy Framework Act, Government Gazette No. 20854, Government Printing Works, Pretoria.

South African Government, 2000b, Promotion of Equality and Prevention of Unfair Discrimination Act, Government Gazette No. 20876, Government Printing Works, Pretoria.

South African Government, 2001, Preferential Procurement Policy Framework Regulations, Government Gazette No. 22549, Government Printing Works, Pretoria.

South African Government, 2014, Employment Equity Amendment Act, Government Gazette No. 37873, Government Printing Works, Pretoria.

South African Government, 2017, Preferential Procurement Policy Framework Regulations, Government Gazette No. 40553, Government Printing Works, Pretoria.

South African Government, 2018a, Broad-based Black Economic Empowerment Act Amendment of Draft Statement 000, Code Series 000 of the B-BBEE Act, Amendment of Draft Statement 000, Code Series 000 of the B-BBE

South African Government, 2018b, Broad-based Black Economic Empowerment Act: Amendment of Draft Statement 300, Code Series 300 of the B-BBEE Act, Government Gazette No. 41546, Government Printing Works, Pretoria.

South African Government, 2018c, Broad-based Black Economic Empowerment Amendment Act as amended by B-BBEE Act (46/53): Draft Schedule 1 for 2018, Government Gazette No. 41709, Government Printing Works, Pretoria.

South African Government, 2018d, Broad-based Black Economic Empowerment Amendment Act as amended by B-BBEE Act (46/53): Draft Code Series 400 for 2018, Government Gazette No. 41709, Government Printing Works, Pretoria.

Thomas, E. \& Magilvy, J.K., 2011, 'Qualitative rigor or research validity in qualitative research', Journal for Specialists in Paediatric Nursing 16(2), 151-155. https://doi. org/10.1111/j.1744-6155.2011.00283.x

Thomas, A. \& Robertshaw, D., 1999, Achieving employment equity: A guide to effective strategies, Knowledge Resources, Randburg.

Topco Media, 2016, Oliver Empowerment Awards, viewed 18 May 2016, from http:// www.oliverawards.co.za.

Valodia, I. \& Francis, D., 2016, 'How the search for a minimum wage laid bare SA's faultlines', Moneyweb Today, 01 December, viewed 01 December 2016, from http://today.moneyweb.co.za.

Vassan, N., 2015, Fact sheet - The revised broad-based black economic empowerment codes of good practice, viewed 21 March 2016, from http://sabpp.co.za/wp -content/uploads/2015/03/SABPP-Fact-Sheet-March-2015.pdf.

Woolley, R., 2014, 'Transformation: A reminder of why we doing this and a reflection of the revised B-BBEE codes', Dr Robin Woolley's blog, viewed 13 June 2016, from http://www.transcend.co.za/resource-centre/blog/robin/transformation a reminder_of_why_we_doing_this_and_a_reflection_of_the_revised_b-bbee codes....html. 